NBER WORKING PAPER SERIES

\title{
THE SECOND WORLD WAR, INEQUALITY AND THE SOCIAL CONTRACT IN BRITAIN
}

\author{
Leander Heldring \\ James A. Robinson \\ Parker J. Whitfill \\ Working Paper 29677 \\ http://www.nber.org/papers/w29677 \\ NATIONAL BUREAU OF ECONOMIC RESEARCH \\ 1050 Massachusetts Avenue \\ Cambridge, MA 02138 \\ January 2022, Revised February 2022
}

We would like to thank Mark Harrison and Arthur Spirling for their guidance to the literature, Daniel Waldenström for his detailed comments, and seminar participants at the London School of Economics for helpful comments particularly Daron Acemoglu, Timothy Besley, Frank Cowell, Steve Machin, Steve Pischke, Ronny Razin and Noam Yuchtman. We also thank an editor and anonymous referee for their advice and suggestions. The views expressed herein are those of the authors and do not necessarily reflect the views of the National Bureau of Economic Research.

NBER working papers are circulated for discussion and comment purposes. They have not been peer-reviewed or been subject to the review by the NBER Board of Directors that accompanies official NBER publications.

(C) 2022 by Leander Heldring, James A. Robinson, and Parker J. Whitfill. All rights reserved. Short sections of text, not to exceed two paragraphs, may be quoted without explicit permission provided that full credit, including $(\odot$ notice, is given to the source. 
The Second World War, Inequality and the Social Contract in Britain

Leander Heldring, James A. Robinson, and Parker J. Whitfill

NBER Working Paper No. 29677

January 2022, Revised February 2022

JEL No. D3,H5,N4,O52

\begin{abstract}
$\underline{\text { ABSTRACT }}$ Britain.

Leander Heldring

Kellogg School of Management

Northwestern University

2211 Campus Drive

Evanston, IL 60208

and briq Institute

leander.heldring@kellogg.northwestern.edu

James A. Robinson

University of Chicago

Harris School of Public Policy

and Department of Political Science

1307 East 60th Street

Chicago, Illinois 60637

and NBER

jamesrobinson@uchicago.edu

Parker J. Whitfill

University of Chicago

whitfillp@uchicago.edu
\end{abstract}

What is the impact of warfare on inequality and the social contract? Using local data on bombing, the evolution of wealth inequality and vote shares for the Labour Party in Britain around World War II we establish two results. First, on average, we find no impact of bombing on inequality. However, there is considerable heterogeneity and this result is driven by the southern Britain. In northern Britain bombing led to significant falls in inequality. Second, heavier bombing led to a significant increase in the vote share for Labour after the War everywhere, but this effect is transitory in the south while it is permanent in the north. Our results obtain both in a simple difference-in-differences framework as well as in a panel-regression discontinuity framework in which we exploit the limited range of German fighter escort planes. Our results provide novel causal evidence for the inequality reducing impact of warfare and we interpret them as consistent with the notion that the impact of the War also led to a reconfiguration of the social contract in 


\section{Introduction}

The existence, sources and dynamics of inequality is one of the most controversial and important set of topics in economics. Inspired by the work of Classical economists like Ricardo or Marx, modern research, spearheaded by Kuznets (1955), initially focused on how the intrinsic dynamics of capitalist development tend to lead to first increasing and then decreasing inequality (Williamson, 1985). Yet recent research has focused more on the impact of large shocks, such as warfare or pandemics, as drivers of inequality and has also emphasized policy choice, not simply the dynamics of accumulation (Scheidel, 2017). Shocks and policies interact, since large shocks may not only have direct effects on inequality, for example through the destruction of assets, or dramatically altering patterns of scarcity, but may also have indirect effects by creating new political coalitions or leading to the re-forging of social contracts with important policy consequences.

In this paper, we examine the direct and indirect effects of World War II (WWII) on wealth inequality in Britain. A literature stemming from Titmuss $(1950,2001)$ has emphasized the indirect channel via which the need to mobilize people and compensate them for the costs and sacrifices of the war led to a more egalitarian social contract. Or as he put it:

"The waging of modern war presupposes and imposes a great increase in social discipline [which] is only tolerable if, and only if, social inequalities are not intolerable". Consequently, war "must influence the aims and content of social policies not only during the war itself but in peacetime as well." (Titmuss, 2001, p. 77-78)

In Titmuss' view, the emergence of the Post WWII welfare state and redistributive policies were a quid-pro-quo which was necessary to get people to tolerate the sacrifices needed to defeat the Axis powers. Titmuss discusses many channels via which individuals were impacted by the war, such as evacuation, the consequences of the defeat at Dunkirk, mass conscription and factory work, but a salient one was simply the effects of wartime damage and destruction. Titmuss argued that the political class quickly realized that this made the status quo no longer tenable.

"the bombing of homes during 1939-1940 stimulated inquiry and proposals for reform long before victory was even thought possible ... The mood of the people changed and ... values changed as well. If dangers were to be shared, then resources should also be shared" (Titmuss, 1950, p. $508)$

Titmuss points out how even the Times newspaper launched leading articles affirming the need for "economic reconstruction" along with "equitable distribution" and argues that "This was a declaration of faith. In 
a few months it was to be repeatedly affirmed with the bombing of London and Coventry and many other cities" (Titmuss, 1950, p. 508). Baldwin concludes his more recent study by arguing "The bombing raids' indiscriminate destruction, blighting Bloomsbury as thoroughly as Brixton, prepared the ground psychologically for a wider sharing of risks" (1990, p. 109).

The direct impact of war destruction on inequality has also received recent attention. Piketty, for example, discussing the impact of the twentieth century World Wars on inequality in France, notes

"most importantly, the physical destructions induced by both world wars were truly enormous in France. According to the best available estimates, about one-third of the capital stock was destroyed during World War I and about two-thirds during World War II" (2003, p. 1020)

Piketty and Saez (2014) attribute one third of the fall in inequality in France and Germany to the consequences of World War II emphasizing the "direct war-related physical destruction of domestic capital assets (real estate, factories, machinery, equipment)" (p. 840). Another third is explained by a fall in asset prices, mostly caused by government policies such as nationalization and taxation.

Titmuss' view dominated the scholarly literature on the emergence of the British welfare state for decades after he wrote (e.g. Addison 1975) but has never been tested empirically. To do so is the objective of this paper. In particular we attempt to research whether either or both the direct and indirect channels are present. To investigate these issues we put together the most comprehensive existing dataset of wealthat-death for all people in England and Wales (we do not have data for Scotland), by year, between 1930 and 1954. Though this data has been examined in aggregate time-series before (for example by Harrison and Atkinson 1978, Alvaredo et al. 2018 and Cummins 2021) the micro-data has never been analyzed empirically. This allows us to construct a geo-located measure of wealth inequality (these 'probate' records record the street address of the deceased from which we identified the latitude and longitude).

To construct a treatment variable, we collected information on the precise location of bombing raids by the German Luftwaffe in England, Scotland, and Wales. Though, as our discussion above suggests, there are numerous channels via which the war impacted people lives, welfare and political views, the direct effects of the damage wrought by bombing is one of the most discussed and obvious channels to investigate. ${ }^{1}$ Moreover, as we discuss below, our identification strategy gives us some leverage on these other hypotheses.

With these two datasets on wealth inequality and bombing we can first investigate the direct effect of bombing on inequality. We do this in two ways. The first is a difference-in-difference analysis, by bombing status, before/after bombing. In the second, we exploit a unique feature of the bombing data. Because of

\footnotetext{
${ }^{1}$ Interestingly, Titmuss' own house in London was bombed during the Blitz.
} 
the range limitations of fighter escorts, there was a limit to how far German bombers could be escorted into England. This allows us to conduct a fuzzy regression discontinuity exercise using the maximum ranges of the German fighter planes from known airfields in France.

Our first set of findings are very consistent across both empirical models. We find no statistically significant effect of bombing on wealth inequality. On the face of it, this is consistent with Alvaredo et al. (2018) who eyeball the time series and detect no large impact of the Second World War on wealth inequality in the United Kingdom.

Our second set of findings concern the indirect effects, in particular whether bombing contributed to the formation of a new social contract. It is not obvious in Titmuss which specific aspect of the war led to this reconfiguration, though as we saw, Titmuss did emphasize the Blitz. Measuring the social contract itself it also challenging. Many of the new policy issues, such as the creation of the National Health Service, were national in scope and cannot be mapped easily onto our local data about bombing. Moreover, in reality, no policy or social change is ever unanimously preferred to another. The most natural approach to this is to look directly at the vote share of the Labour Party at the level of a parliamentary constituency (aggregating the bombing data to this level). As we discuss shortly, it is clear that in the 1945 general election the Labour Party was more committed to the vision of the 1942 Beveridge Report, which laid out a vision of a new post-war social contract, than were the Conservatives. Therefore, we hypothesize that if the effect of bombing was to stimulate the demand for a new social contract, as Titmuss conjectured, then this would show up in a positive correlation between bombing and the vote share of the Labour Party.

To analyze the indirect effects on the social contract we use the same difference-in-differences and regression discontinuity models. In the difference-in-differences model we find that a large and persistent increase in the vote share of the Labour Party is associated with high bombing intensity. However, in contradistinction, in the regression discontinuity analysis, we find this effect to be there only in 1945. By the 1950 general election it goes away.

It turns out there is a simple explanation for these differences which is very revealing about both the direct and indirect effects of bombing on inequality: there is significant heterogeneity between the south and the north of Britain (split according to median latitude). When we re-do our analysis breaking the sample into the north and south, our difference in difference results shows large negative effects of bombing on inequality in the north, but nothing in the south. Our initial average zero effect was driven by the south. Since the study boundary in our regression discontinuity is in the south (the German bombers came from France and the Low Countries) these results do not change. Turning now to the vote share for the Labour Party as the dependent variable, we find that the persistent change in the basic difference-in-differences analysis is driven entirely by the north. For the south, the difference-in-differences analysis is identical to 
our regression discontinuity analysis: there is a significant increase in the vote share of the Labour Party in 1945 in heavily bombed areas, but not afterwards.

We interpret these results in the following way. The difference between the direct effects of bombing in the north and the south is that in the north the bombing was far more targeted at ports and industrial centers, like Leeds, Newcastle, Sheffield, Sunderland and Middlesborough, wiping out significant amounts of capital and top wealth which were never recovered. We support this interpretation by showing that there is a persistent negative effect of bombing on average wealth in the north. This did not happen in the south because there the bombing was far less focused (at least partially intended to undermine "morale") and impacted rural areas and residential parts of London, as well as ports and industrial areas.

With respect to the indirect effects, we believe our results are consistent with the notion that bombing reconfigured the social contract. In 1945 there was an average shift towards the Labour Party which is causally related to bombing intensity. The obvious interpretation of this is that wartime destruction shifted peoples' preferences towards the type of welfare state that Beveridge had promised but which only the Labour Party was committed to. The reason this shift lasted only until 1951 was that Labour delivered in a permanent way large parts of this agenda, particularly the National Health Service (NHS). Once this was created, other political issues became salient and voters in the south switched back to the Conservatives. In the north, the persistent negative impact of the bombing on average wealth gave other grounds for people to continue to vote Labour, despite the fall in inequality which it also induced.

Though our focus on bombing might be thought overly narrow, in fact our regression discontinuity analysis is telling about the plausibility of other channels. For example, for our 1945 election result to be driven by other mechanisms, such as wartime recruitment into military service or factory employment, these factors would have to jump discontinuously at the bombing boundary, which seems implausible. It might be thought that evacuation might jump at the discontinuity and detailed pre-war plans did logically take into account the likely penetration of German aircraft. Yet, "plan 2", formulated in January 1939 designated broad areas for evacuation, focused on London (see Titmuss 1950, p. 33) and the detailed discussion in Titmuss 1950, Chapter 3, provides no evidence that evacuation was fine tuned to match our boundary. Despite recent skepticism about Titmuss' arguments, therefore, we interpret our evidence as being highly consistent with his original emphasis on the consequences of bombing and wartime destruction.

These findings offer quite a few innovations over the existing literature. First, while as we noted above, scholars have proposed important impacts of war destruction on inequality in France and Germany, the consensus seems to be that Britain was "little hit by war destructions" (Piketty, 2011, p. 1077) and that this was a case "where domestic capital destruction was of limited importance" (Piketty and Saez, 2014, p. 840). This view is echoed by British historians with Edgerton noting "In world war II the impact of 
bombing as a collective threat has been exaggerated - it lasted only for some months and only applied to certain restricted places" (2018, p. 223). In fact we show that wartime destruction had an enduring negative impact on inequality (and wealth) in the north. ${ }^{2}$

Second, our results shed new light on the debate about the accuracy of Titmuss' hypothesis. Recent research has tended to reject this on the grounds that in fact there was no consensus about the creation of a welfare state or the type of society that English-people wanted to see after 1945. There was therefore no new social contract of the type Titmuss postulated. Historians illustrate this by pointing out that large differences that remained between the Labour and Conservative parties even after the wartime coalition government accepted the recommendations of the 1942 Beveridge Report. ${ }^{3}$ Though the coalition government did finally produce a white paper in 1944 outlining commitment to Beveridge's vision, there were large gaps in reality. Baldwin notes that the initial reaction to it by the Conservative party, which appointed a secret committee to report in response to it was to "criticize many of Beveridge's recommendations as extravagant and socially debilitating" (1990, p. 130). Harris, in a wide-ranging review of this issue observes "the lack of commitment to social reformist issues shown by Churchill and his closest advisers" (Harris, 1992, p. 27). Jefferys states "the emergence of a consensus between the parties during the war has also been overstated" and he points to the "the deep-seated differences which continued to exist between the Conservative and Labour parties over welfare reform" (1987, p. 124). Moreover, "Conservative and Labour members in parliament were ... not agreed upon the need for a fundamentally new approach to social welfare" (1987, p. 124). ${ }^{4}$ Harris emphasizes not just the lack of consensus amongst the politicians, but also amongst the people, for example as revealed by the Mass Observation project undertaken during the war to monitor the country's morale (Harris, 1992).

We agree that there was no consensus about many of Beveridge's reforms, but it is plausible that they were overwhelmingly popular. Todman, in the most recent historical synthesis of this period concludes

"The scale of the country's military endeavour during the war had been such that the ideas of fairness and mutual obligation inculcated by service became an influential factor once 'normal' electoral politics resumed" (2020, p. 761).

Likewise Kynaston (2007) though he criticizes Titmuss' 1950 book for its "Whiggish, feel-good reading

\footnotetext{
${ }^{2}$ What "little hit" means in reality is not clear. Over the entire 1939-1945 period 62,000 civilians were killed by "enemy action" nearly all by bombing raids (Titmuss, 1950, p. 559); around 400,000 were injured (p. 560); over 4 million people were evacuated from their homes (pp. 563-564); 3,745,000 different houses were damaged or destroyed, about 2 out of every 7 (p. 330); $20 \%$ of all schools were damaged or destroyed (p. 331); and of course there were heavy damages to factories, manufacturing industry and infrastructure facilities such as railways and ports.

${ }^{3}$ There is a parallel and more vitriolic literature by historians and public intellectuals attacking Titmuss for painting a romanticized vision of the "Blitz culture" (Titmuss himself remarks "Dunkirk, and all that the name evokes" (1950, p. 508)). This literature argues that this whole notion is a construction of wartime propaganda and does not reflect what actually happened during the war, see for example Calder (1991) and Ponting (1993).

${ }^{4}$ See Smith (1986) and Lowe (1990) for other important contributions to this perspective.
} 
- unity forged through adversity, irresistible pressure from below leading to longed-for change" (p. 40) nevertheless accepts that in fact, with respect to Titmuss' main argument, "there were plausible grounds for it". To be correct, Titmuss' thesis does not require that everyone was in favor of a welfare state. In fact, it is exactly this point which motivates our use of the Labour Party vote share as a measure of the support for a new social contract since in 1945 they, but not the Conservatives, were committed to it. However, once the Attlee Labour government delivered on its promises, "Its historic mission seemed to be fulfilled" (Hennessey, 2006, p. 423), ${ }^{5}$ innovations like the NHS were a fait accompli, and by the 1950 and 1951 elections what became known as "Butskellism" emerged, whereby the Conservatives became reconciled to the welfare state. With this issue off the table, people in the south who had voted Labour switched back to the Conservatives. Our results therefore re-instate at least some notion that bombing did create a general reconfiguration of the social contract. ${ }^{6}$

The lack of commitment to the Beveridge report on the part of the Conservative party is particularly evident with respect to its vision of universal health care under a government run National Health Service (NHS). Hennessey notes "Those who argue that the NHS as it was eventually constructed was very largely the creation of Coalition thinking tend to forget the weakling of a scheme ... left in place when the Government changed in July 1945" (2006, p. 135). In his view it was the Labour victory that delivered the NHS. Edgerton concurs stating "The NHS as it emerged was clearly not something the Conservatives would have enacted" (2018, p. 220) and Jefferys similarly points out "the important differences between the coalition plan of 1944 and Labour's subsequent legislation" (1987, p. 133) and he quotes Lord Woolton, Minister of Reconstruction as saying that "the working out of the new health service would be very different under a Conservative Government than it would be under a Socialist Government" (1987, p. 136).

Differences were evident to voters not just with respect to the form of healthcare. Jefferys argues "For the Conservative leadership, unemployment in the post-war years was to be avoided - if not by a return to pre-1939 conditions - by a heavy reliance on traditional remedies: the stability of sterling, the revival and expansion of export trade, and above all the encouragement of private enterprise" (1987, p. 138). Todman observes on the part of the Conservatives "a mismatch between the talk of fiscal orthodoxy and removal of controls and promises of improved social services" (2020, p. 752).

Our research is related to several other literatures. Most notably Scheve and Stasavage (2016) developed a social contractarian argument for the correlation between the world wars and higher rates of taxation on the rich. In their argument, the poor agreed to fight and the rich agreed to pay taxes in compensation. Though our analysis is in the spirit of their research it should be clear from the above discussion that our

\footnotetext{
${ }^{5}$ King notes "The fit between what the Labour Party said it would do in 1945 and what the Labour Government actually achieved between 1945 and 1951 is astonishingly close" (1975, p.163).

${ }^{6}$ See McCallum and Readman (1964) and Crowcroft and Theakston (2013) on the 1951 General Election.
} 
regression discontinuity results are not consistent with their mechanism for which they provide no direct evidence. Relatedly, Goodin and Dryzek (1995) propose an alternative mechanism whereby wartime sacrifices lead to subsequent redistribution, though they do not explore this empirically (for a more normative account see Dryzek and Goodin 1986). A series of papers, particularly Davis and Weinstein (2002), Miguel and Roland (2011), and Dell and Querubín (2018) have studied - in different contexts - the long-run impact of bombing during wartime. The main finding of all three papers is that there are no persistent effects of bombing on the size distribution of cities, development or rebel activity respectively. Our focus is very different and none of these papers examine the effects on inequality or investigate whether bombing might have had implications for the social contract. Finally, there is a large and multi-faceted literature on the social, economic and political consequences of warfare. The connection has been made to democratization (Therborn, 1977; Acemoglu and Robinson, 2000; Aidt and Jensen, 2014), state building (Tilly, 1990; Besley and Persson, 2011) and specific policy initiatives like income taxation (Aidt and Jensen, 2009). None of this literature has empirically investigated the impact of war destruction as a source of variation, nor to our knowledge examined voting behavior as a specific outcome.

\section{Data and measurement}

In this section, we introduce the unit of observation and the data that form the basis of the empirical part of our paper. Our focal outcomes are wealth inequality and voting behavior, in particular the vote share of the Labour Party. For wealth inequality our data cover England and Wales, and for voting our data cover England, Wales, and Scotland. We observe our treatment variable, bombing, for England, Wales, and Scotland as well.

\subsection{Unit of Observation}

Our unit of observation depends on which of our two main outcomes we study.

Wealth and inequality. For economic outcomes, such as per capita wealth and the Gini coefficient, the unit of observation is a registration district, which is an administrative region used for the civil registration of births and deaths. We choose this unit of observation so that we are able to combine individual data on recorded wealth with data on population, which allows us to record individuals that are too poor to have any recorded wealth. Population figures are recorded at the registration district, and we therefore use these as our unit of observation. There are around 600 registration districts in England and Wales which are used in our study. We measure registration districts as recorded in the 1911 census and use these as consistent units throughout our study. 
Voting. We measure voting at the level of the parliamentary constituency. In each constituency, voting determined which Members were sent to Parliament (MPs). There are around 600 constituencies throughout England, Wales and Scotland within our sample period, but they are not consistent over time. We take constituencies as they existed between 1918-1945 as our unit of observation and conform border changes that take place after 1945 to the 1918-1945 constituencies. For example, if in 1955 a constituency is split into 2 constituencies, we take the average of a variable across these two split constituencies and assign this average to the 1918-1945 original constituency.

\subsection{Treatment: War time bombing}

To measure the local impact of the War, we collect novel bombing data from the Ministry of Home Security's Daily Intelligence Reports, which were recently digitized. The Intelligence reports record the locations of over 30,000 bombing raids in England, Wales and Scotland over the course of WWII. Each raid is defined as any aerial attack with intent to destroy, geocoded to the location the bombs hit. We assign the location of each raid to a registration district or a constituency.

Naturally, the sizes of constituencies and registration districts as well as the intensity of bombing vary. We therefore transform the number of bombs within a unit of observation in two ways. First, normalize by unit of observation area: $\frac{\text { number of bombing raids }}{\text { square } \mathrm{km}}$. Second, to account for the large tail of bombing intensity we transform our normalized bombing intensity in two further ways. ${ }^{7}$ First, in our preferred specification we split bombing intensity by median intensity, creating an indicator which is equal to one if a unit of observation was bombed intensively. Second, in the Appendix we show all our results are robust to exploiting the full range of bombing intensity. We also omit London from our baseline analysis.

We visualize our binary bombing intensity measure for parliamentary constituencies in Figure 1. There are two important things to note. First, bombing in the north and south appear qualitatively different. In the south, and in the south-east in particular, constituencies are uniformly bombed more intensively, but in the north intensive bombing appears concentrated on industrial centers, such as Liverpool or Newcastle. Because of this heterogeneity in bombing intensity between north and south, we study heterogeneous effects by these areas throughout the empirical part of this paper. We define the north as the area of Great Britain with a latitude greater than the median latitude in our sample of constituencies. Appendix Figure 11 plots north-south border.

\footnotetext{
${ }^{7}$ While the median bombing intensity is around .17 and almost all units of observation see less than one bombing raid per square kilometer, there are parts of London with a bombing intensity over 100 .
} 


\section{$2.3 \quad$ Wealth}

To measure wealth and wealth inequality, we use the United Kingdom's Principal Probate Registry Calendars which record individual names, addresses and the value of assets for people who are liable to pay inheritance tax. See Figure 2 for an example of what the original data looks like. We digitize all records available between 1930 and 1954 using OCR technology. Because each person has a location of their home included in their probate, we are able to geolocate each probated individual and assign them to a registration district. We can use the resulting dataset to compute our measures of interest, such as average per capita wealth or the Gini coefficient of wealth. Probates needed to be filed based on a wealth cutoff. Cummins (2021) documents the proportion probated each year and the probate threshold each year. Somewhere between $30-70 \%$ of individuals who pass away in a given year are probated, depending on the year. As a robustness check on the potential impact of the varying probated individuals, we augment the probate data with records on the total number of deaths in each registration district. Using this data, we can infer how many individuals are missing from the probate data. Following Cummins (2021), we can impute the wealth of those not in the probated sample by assigning them half of the probate threshold. This procedure allows us to recover a measure of wealth for the full population, rather than only for those people wealthy enough to be probated. However, even this process is imperfect because it is still impossible to know if an individual that does not show up in the probate data was too poor to be probated or was lost due to OCR errors in digitizing the original material. We therefore estimate our main results for probated individuals only. In the Appendix, we re-estimate all results using our best reconstruction of the entire population. $^{8}$

\subsection{Voting}

To measure support for the Labour Party we record the vote share of each party in each election between 1918 and 1970 from Watson et al. (2020). Our primary outcome variable in voting is Labour's vote share in a constituency.

\subsection{Other Variables}

We use several covariates. These include electorate size, population size, and the type of constituency, either county or borough (corresponding roughly to towns and countryside). We introduce these as they become relevant in the paper.

\footnotetext{
${ }^{8}$ Sometimes, the literature using wealth-at-death data attempts to impute wealth-while-alive using a mortality multiplier. We do not do this because there is no age data in the probated records.
} 


\section{Results: Difference-in-Differences}

In this section, we present our first set of results in a difference-in-differences framework. After introducing the estimating equation, and discussing inference, we first estimate the relationship between the impact of the War, as captured by bombing, on inequality. We find a small and insignificant average effect. In the north, however, we find a negative and statistically significant effect whereas for the south we estimate a precise zero effect. We then estimate the effect of the War on votes for Labour. We find that, on average, the War leads to a shift in voting patterns in favor of Labour. In the south this effect is only present for the first immediate post-war election, whereas the effect persists in the north.

\subsection{Estimation Equation and details}

Our estimating equation takes a standard panel difference-in-difference form. We estimate this equation using ordinary least squares (OLS)

$$
Y_{c t}=\gamma_{t}+\rho_{c}+\sum_{r \in R} \beta_{r} D_{c} 1\{t=r\}+\zeta X_{t}+\epsilon_{c t}
$$

The variable $Y_{c t}$ is the outcome of interest, either the wealth Gini or Labour's vote share for unit $c$ in year $t$, where $c$ is either a registration district or a parliamentary constituency, respectively. $D_{c}$ is an indicator for being above median bombing intensity over the War, defined above. $X_{t}$ are covariates mentioned above. The model includes time $\gamma_{t}$ and unit $\rho_{c}$ fixed effects. We omit the last pre-period before the start of the War, unless otherwise noted. For our Gini data this corresponds to 1938, while for our Voting data this corresponds to 1935. Therefore, we express all estimated effects relative to this omitted year. $R$ is the set of years in our sample that are not omitted.

The first coefficients of interest are $\beta_{t}>=1939$, which estimate the effect of bombing intensity in year $t$. The key identification assumption is the parallel trends assumption: Absent treatment, treated units would have evolved on parallel trends with non-treated units. This assumption is untestable, but we study pre-trends to study whether this assumption is plausibly met. Specifically, we study coefficients on the pre-period bombing-indicators, $\beta_{t}$ for $t<=1938$, to see if bombed and non-bombed places are evolving similarly before treatment. We report heteroskedasticity-robust standard errors, clustered at the unit level.

The main challenge to inference in such designs is the problem of correlated shocks. As the War clearly impacts many aspects of society, it may be the case that there are others shocks that coincide with bombing and correlate with its spatial incidence. This is a fundamental challenge to any difference-in-differences design. In section 4 when we consider a regression discontinuity design that attempts to alleviate this issue. 


\subsection{Wealth Gini}

Our first outcome of interest is the Gini coefficient of wealth at death. We begin our analysis by looking at simple mean differences in our complete sample by bombing status in Figure 3. For both intensively and non-intensively bombed registration districts, the Gini coefficient falls by about 0.05 around the start of the War. In terms of magnitude, it is similar to earlier jumps or drops in the time-series (not all shown). This is consistent with the conclusions from Alvaredo et al. (2018), who observed a fall in wealth inequality around WWII, but it is not large nor obvious that the fall is directly attributable to WWII. Moreover, in all years before 1939, bombed and non-bombed districts appear to be evolving similarly. After 1939, there appears to be no or at most a small change in the Gini coefficient for highly bombed places compared to non-highly bombed places.

We probe these preliminary conclusions by estimating equation 1. We present our results graphically in Figure 4 where we plot estimated coefficients and confidence intervals, year by year. Pre-treatment coefficients measure the presence of pre-trends, while the post-period coefficients capture the average treatment effect of being bombed intensively over the course of the War, in year $t$. The first result in Figure 4 is that pre-1939 coefficients are not significantly different from zero, pointing to parallel pre-trends which, in turn, lends credence to our claim that the parallel trends assumption is met. We fail to reject a joint F-test for the null hypothesis that all the pre-period coefficients are 0 . Our second result pertains to the post-treatment coefficients. By and large, the post-treatment coefficients are indistinguishable from zero and are all economically rather small, around 0.01. A joint F-test of all post-1938 coefficients indicates a small overall negative effect. ${ }^{9}$

We anticipate that this result may be qualitatively different over space, as our map in Figure 1 suggests that whereas the south, especially around London, was uniformly bombed, bombing in the north appears concentrated in and around industrial cities. In the next section, we therefore break our results up by this division.

\subsubsection{Heterogeneous Effects}

To investigate heterogeneous effects, we break up our sample into north and south Britain. We then reestimate equation 1 in each sample. Figure 5 presents results from both regressions in one coefficient plot.

\footnotetext{
${ }^{9}$ The most important robustness concern pertaining to these results is the nature of our wealth data. A natural concern is that capital is held by people all over the country, while the owners of capital live in London. Since all our regressions compare local bombing to local outcomes, we might be mismeasuring local wealth outside London. In the Appendix, we perform the following check: We see whether there is a change in wealth of those living in London when areas outside London are bombed. If we see a correlation, this could be consistent with our concern. We find no correlation, and we interpret this finding as indicating that this measurement concern is not quantitatively important. We implement several additional robustness checks. We first check robustness to varying the way we measure bombing. Instead of binarizing bombing, we use the inverse hyperbolic sine transformation of the number of bombing raids, and find similar results.
} 
We find substantial heterogeneity between north and south. In the south, we observe no effect of bombing whereas in the north, there is plausibly a negative effect. Almost every year after treatment, the coefficients are about -.025 . Because of the lower sample sizes, estimates are more noisy, but 1945, 1949, 1952 and 1954 are significant at the 5\% level, while 1947 and 1953 are significant at the $10 \%$ level. These results show the advantage of looking at the micro-data, as these heterogeneous effects run in contrast to Alvaredo et al. (2018)'s conclusion that WWII has a small direct effect on wealth inequality (which was based on the aggregate time-series). Our new data allows us to bypass the aggregate to view these more granular heterogeneous effects. These results show that the small negative aggregate effect is driven by the north. In our introduction, we interpreted this effect as being driven by differential targeting of industrial centers vs more broadly targeted bombing in the south. We return to this point below.

In sum, we find that bombing has a significant negative effect on wealth inequality in the north, and no effect in the south. On average, and in line with the previous literature on this topic, there is an economically insignificant effect of bombing.

\subsection{Voting}

In this section, we study voting patterns for Labour. In the introduction, we reviewed the historical literature on the post-war success of the Labour Party, and the potential role of the War in generating support for redistribution. In this section, we use the share of the vote going to Labour in a parliamentary constituency as a measure of this change, and we relate it to bombing intensity.

As with the Gini coefficient, we present our results in a few different ways. First, Figure 6 presents sample means of Labour's vote share split by bombing intensity. Note both the large increase in the vote share for Labour in 1945 (about 15 percentage points) and the differential increase for intensively bombed and non-intensively bombed places. Note also the parallel movement of the vote shares between intensively and less intensively bombed parts of Britain. The overall increase in Labour vote share in 1945 has been extensively studied, as we document in the introduction. However, the differential rise in bombed versus non-bombed places is a new stylized fact that we add to the literature. This more 'micro' fact is fully consistent with the argument of Titmuss $(1950,2001)$ that bombing caused an increased demand for redistribution in the form of a new social contract (which manifested itself as votes for the Labour Party which was committed to this policy).

Figure 7 presents formal regression estimates of equation 1 with voting as the outcome variable. The coefficients on the pre-period bombing indicators are all not significantly different from 0 before 1945, indicating the parallel trends assumption holds. A formal F-test that all the pre-period coefficients are 
jointly 0 fails to reject this hypothesis. After the War, the estimated coefficients for bombing increase to around 4 percentage points starting in 1945, indicating a large treatment effect and a shift in voting patterns towards Labour. Interestingly, the effect persists until the last period for which we have data, 1970. Labour appear to be getting a 4-5 percentage point advantage in every election after 1970.

To get an intuitive sense of the magnitude of this effect, we estimate how many seats Labour could attribute to bombing and if its parliamentary majority hinged on these seats. While this is generally not possible to estimate, it is feasible if we assume constant treatment effects. With constant treatment effects, each constituency's counterfactual Labour vote share can be calculated as

\section{Current Labour Vote Share $-1\{$ Above Median Bombing $\} *$ Average Treatment Effect}

where we take the average treatment effect from our estimate of equation 1 . Table 2 shows this advantage consistently delivered at least 20 seats and without this advantage Labour would have lost the 1950 election. While the treatment effect is large in the first few elections after the end of WWII, 1945 was a landslide for Labour, so this effect only becomes decisive when the election was close in 1950.

\subsubsection{Heterogeneous Effects}

As before, we split our sample by the north and south of Britain and re-estimate equation 1 in each sub-sample. Figure 8 plots both coefficients. Once again we see interesting heterogeneity. The effect of bombing on voting in the south is transitory and wanes after the immediate postwar election, whereas the persistent average effect we find is driven by the north, where Labour retains its advantage. We interpreted these results in the introduction as being consistent with the reconfiguration of the social contract. Throughout the country in 1945 voters shifted to Labour the more they suffered from bombing and this reflected sentiment in favor of the social changes proposed by Beveridge. But these different voting patterns were only transitory in the south. When the Labour government delivered, southern voters went back to supporting the Conservatives. In the north the shift persisted, despite the fall in wealth inequality. Why this might be do is revealed by Figure 9 which instead of looking at wealth inequality uses the probate records to construct a measure of per capita wealth at death. Here we see a sustained negative impact of bombing on average wealth in the north but not in the south. This seems plausibly related to the relatively more focused bombing in the north on industrial and port complexes. Plausibly this destroyed capital and businesses that never recovered and this hysteresis created economic problems, such as unemployment and poverty which show up in the average wealth data and are reflected in the vote share of the Labour Party. These mechanisms did not operate in the south. 
From an identification perspective, the main problem with difference-in-differences estimates are correlated shocks. The War clearly not only involved bombing, but also factors like military recruitment, the creation of war industries, and population movements. These factors may well be correlated with bombing patterns and thus may invalidate our interpretation of our estimates. To address this concern, we re-estimate the effect of WWII bombing in a regression discontinuity framework.

\section{Results: Regression Discontinuity}

In this section, we implement a regression discontinuity design within our panel dataset. As we will see, this provides evidence which is very consistent with our earlier results.

\subsection{Historical Background}

During the Battle of Britain, Germany engaged in a massive air assault on Britain. To bomb Britain, Germany needed both bombers and fighters. If bombers were sent without fighters, especially during the daytime, the causality rate of the bombers could not "hold the loss rate down to acceptable levels" (Murray, 2015, p. 46). While some bombers were nonetheless sent without fighters, especially to the northern and eastern ports of Britain, how many bombers could be sent to any place in Britain was influenced by the presence of fighter escort planes. These planes had more limited ranges than bombers, creating a range within England below which escort planes could easily accompany bombers and above which escort planes had to turn back. We posit that this limited range of escort planes creates a natural discontinuity in the probability of a place being bombed intensively.

The main escort plane the Germans used at the start of the War was the Messerschmitt BF 109E. These fighters had a 'combat radius' of around 125 miles, meaning a fighter could reasonably expect to have enough fuel to take off, fly 125 miles, fly back 125 and land (McNab, 2012; Mawdsley, 2020). This limited combat radius was because the BF 109E's were designed primarily for defensive flight rather than offensive fight (Murray, 2015). The range limitation lasted throughout the Battle of Britain, and it did not loosen until drop tanks were added to the BF 109F in 1941. The large effect of the range limitations of the BF 109E's on the Battle of Britain has been noted extensively before. The Luftwaffe themselves considered range a major factor in where they planned to bomb. For example, pilot Oberstleutnant Adolf Galland even noting in his autobiography that "Germany fighter squadrons ... (were) barely able to cover the south-eastern part of England" (McNab, 2012).

We collect the full population of airfields used by the Luftwaffe throughout WWII in France, Netherlands and Belgium. Then we subset this collection to the airfields used for BF 109Es in the Battle of Britain as 
per Mawdsley (2020) and Murray (2015). Using this data, we can see the limited range of the escort planes visually in Figure 10. We hypothesize that the BF 109E's range limitation generates a fuzzy regression discontinuity where the cutoff is 125 miles from the bases where BF 109Es were stationed.

To operationalize this idea we compute, for each observation in our dataset, the distance in miles to the nearest base and based on this distance we compute an indicator for whether a place is within reach of the BF 109Es. ${ }^{10}$

\subsection{Estimation}

To implement the fuzzy regression discontinuity design, we estimate the following set of equations

$$
\begin{gathered}
Y_{c t}=\gamma_{t}+f\left(\text { location }_{c}\right)+\sum_{r \in R} \beta_{r} D_{c} 1\{t=r\}+\epsilon_{c t} \\
\left.D_{c} 1\{t=r\}=\gamma_{t}+f \text { (location }_{c}\right)+\sum_{r \in R} \alpha_{r} Z_{c} 1\{t=r\}+u_{c t}
\end{gathered}
$$

In the first equation, $Y_{c t}$ is the outcome of interest. $f\left(\right.$ location $\left._{c}\right)$ is some function of the location of each unit. We use either straight-line distance to the discontinuity, latitude and longitude, or simply unit fixed effects. Because unit fixed effects capture the most information about location, we use these as our baseline specification but vary this in the appendix. $D_{c} 1\{t=r\}$ is an indicator of whether the unit is above or below median bombing intensity times an indicator for the time period. The $\beta_{r}$ are our coefficients of interest as they capture the measured effect of being just above the discontinuity in space at a given point in time. $\mathrm{R}$ is the set of all years, omitting only the last pre-period before the start of the War, so that we obtain point estimates for every other year in our panel. $\gamma_{t}$ are time fixed effects, and $\epsilon_{c t}$ is a heteroskedasticity robust standard error, clustered at the unit level.

Because we estimate a fuzzy $\mathrm{RD}$, we instrument $D_{c} 1\{t=r\}$ in equation 2 . The instrumental variables are $\sum_{r \in R} \alpha_{r} Z_{c} 1\{t=r\}$ where $Z_{c}$ is an indicator for being in range of the BF 109Es. $Z_{c}$ is interacted with period indicators so that we estimate each period effect separately. We again fully saturate $R$, omitting only the last pre-period before the start of the War. $\gamma_{t}$ and $f\left(\right.$ location $\left._{c}\right)$ are the same as in the second stage equation. $u_{c t}$ is clustered like in the second stage.

While our estimation procedure closely resembles a typical cross-sectional RD design, the fact that

\footnotetext{
${ }^{10} \mathrm{~A}$ natural challenge to this approach is the fact that our geographical units of observation, constituencies or districts allow several ways to compute distances between them and the geocoded points of the airfields. In our main analysis we use an indicator that is 1 if any part of the unit of observation is in range. In the Appendix, we implement two other methods. First, we use the closest point in the geographic unit to the airfield. Second, we compute the percent of the geographic unit within range and use this as the variable of interest, rather than a binary indicator.
} 
we use a panel dataset weakens some identification assumptions. Most importantly, in a standard crosssectional RD design, the key identification assumption is that nothing else changes discontinuously at the cutoff. In our panel design, any time-invariant unobservables are captured by unit indicators. In our setting, our identification assumption is therefore that there is no time-varying discontinuities that either appear or change in magnitude over time. Validating the absence of 'pre-trends' naturally extends to this setting. The presence of a pre-trend would suggest that there were time-varying discontinuities at the cutoff in the years before treatment began. We are not aware of any data-driven way to choose a bandwidth for a regression discontinuity in a panel setting. We will show that our results hold for a wide range of bandwidths.

\subsection{First Stage}

The informativeness assumption of our research design requires that being outside the BF 109E's combat range correlates sufficiently strongly with the probability of being bombed intensively. To build intuition for our assertion that this is in fact the case, we present a map of the combat radius of BF 109Es as well as which constituencies were in range in Figure 10. The constituencies in the south with above median bombing almost all within range of the BF 109Es, while the constituencies outside of range are rarely bombed heavily. We formally extend this exercise to our results by noting that the first stage F-statistics for each of our endogenous variables is well over the conventional threshold of 10 .

\subsection{Wealth Gini}

We first turn to our results for the wealth Gini coefficient. We estimate the system of equations 2 and 3 in Figure 11. We plot the coefficients by period. For any bandwidth between 25 and 50 miles, we do not find any change in Gini around the boundary after 1939, nor any evidence for pre-1939 discontinuities. This result is consistent with our diff-in-diff estimates for the south.

\subsection{Voting}

Figure 12 implements the regression implementation of equations 2 and 3 with Labour Vote Share as $Y_{c t}$, and plots the coefficients of interest. Consistent with our previous results, we find a positive effect on the vote share for Labour, but only in 1945, with a positive effect around $8 \%$ of the vote share. This qualitatively replicates the result of the difference-in-difference in the south. Moreover, no pre-period coefficients are significantly different from 0 . 
An important advantage of these regression discontinuity results is that other consequence of the outbreak of the War that vary locally, such as military recruitment, are less likely to vary discontinuously (over time) over our study boundary. As we discussed in the introduction, prominent explanations for the impact of war on the social contract suggest that this works via the burdens that people had to bear serving in the army or in wartime occupations, or perhaps via evacuation. While these channels may be important, they cannot be an interpretation for our regression discontinuity findings.

\section{Conclusion}

In this paper, we estimate the direct and indirect effects of bombing on wealth inequality in Britain during World War II. The indirect effect works through the impact of bombing on the social contract and thus policies (Titmuss, 1950) and has long been hypothesized to be important: the War created a coalition among voters for social reform which was then implemented by the Labour Party, leading to a reduction in (wealth) inequality in England and Wales. The direct effect is simply the impact of the destruction of assets and the capital stock on inequality.

We combined data on all bombing raids in Britain during WWII and a comprehensive dataset on wealthat-death and votes for Labour to test these effects. In difference-in-differences and regression discontinuity frameworks we find several key pieces of evidence. First, and contrary to the conventional wisdom, we present novel evidence that bombing significantly reduced wealth inequality in the north of Britain, but not the south. We argued that this was due to the different focus of the bombing. Thus the direct channel operated at least in part of Britain. Second, we found support for the indirect effect. Places that were bombed more heavily changed their votes in favor of Labour in 1945 and Labour delivered, implementing sweeping social change. After 1945, voters in the south went back to voting Conservative, but voters in the north kept voting for Labour. This is likely due to the fact that the reforms implemented by Labour, particularly the creation of the NHS, were deemed permanent, and the heterogeneous impact of bombing in the north and south. In the north, bombing was aimed at targeting productive capacity and resulted in a permanent fall in the average level of wealth giving persistent reasons to move towards the Labour party. This fall did not occur in the south so that once the NHS was institutionalized, voters permanently got the part of the social contract they most valued and were able to cast their votes according to other issues.

We did not provide evidence that these policy changes reduced inequality because most were national in scope and do not vary at the local level we exploit in the analysis. However, it seems highly plausible that the new redistributive policies did indeed contribute to falling inequality. 
We interpret these effects as consistent with Titmuss (1950)'s emphasis on the changes in the social contract that occurred as a consequence of WWII. 
Figure 1: MAP OF BOMBING INTENSITY IN WORLD WAR II

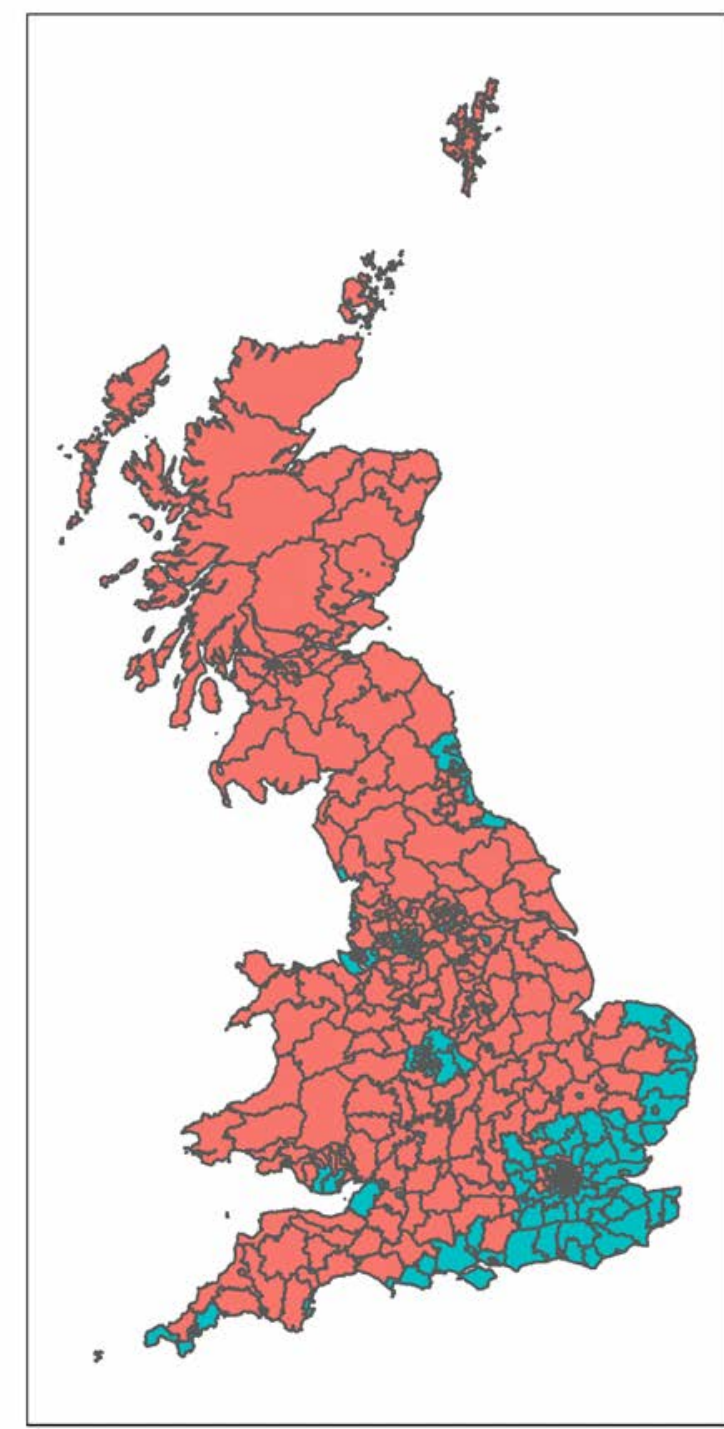

\section{Bombing Intensity (Binary) $\square 0 \square 1$}

Notes: Bombing Intensity (Binary) is the median split of bombing intensity, which is defined as the $\frac{\text { number of raids }}{\text { square } \mathrm{km}}$ between 1940 and 1945, with 1 being above median and 0 being below median. The unit of observation in the Parliamentary constituency. 
Figure 2: EXAMPLE OF PROBATE RECORDS

\section{1}

FALDER Gladys Laura of 45 Sedgemere-avenue East Finchley Middlesex spinster died 10 October 1940 at 110 Follingtonpark Islington London Probate Llandudno 12 March to Josephine Muriel Norah Falder spinster. Effects £196 11s. 2d.

FALK Herman John of The Warneford Oxford died 11 February 1941 Probate Oxford 3 June to Oswald Toynbee Falk company director. Effects $£ 9643$ 19s. 7d.

FALK Mary Gertrude Catherine of Thorshill West Kirby Cheshire (wife of Herman John Falk) died 2 October 1937 at 40 Harleyhouse Marylebone-road London N.W.1 Probate Llandudno 4 April to Arthur Lincolne Hitchcock Spencer engineer. Effects $\$ 4853$ 3s. 3d.

FALKENBERG Carl of 42 Henderson-road Sunderland died 10 September 1941 Probate Durham 3 November to Signe Beck spinster. Effects 11480 4s. ld.

FALKENBERG Charlotte Louise of 42 Henderson-road Sunderland spinster died 20 October 1940 Probate Durham 25 February to Signe Beck spinster. Effects $\$ 774$ 10s. Id.

FALKINER Hannah of Elmshurst Old Station-road Hampton-inArden Warwickshire widow died 22 August 1941 Probate Llandudno 8 October to Alfred Edward Ferris solicitor.

Effects $£ 6380$ 7s. 4d.
FALKNER Mary Ann of 68. Alcester-road Moseley Birmingham (wife of Albert Frederick Falkner) died 5 November 1940 at Queens Hospital. Birmingham Administration Birmingham 27 February to the said Albert Frederick Falkner journeyman joiner. Effects $£ 688$ 13s. 11d.

HOPE-

FALKNER Percy of The Union Club Valetta Malta died 9 October 1940 at Birkirkara Malta Probate Llandudno 29 April to Messrs Holt and Company Trustees. Effects $\$ 4706 \mathrm{19s}$. 10d.

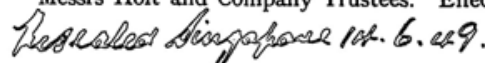

FALL Alice Mary of 21 Westbourne-grove Ripon spinster died 26 October 1940 at 75 Allhallowgate Ripon Administration Wakefield 10 December to Elizabeth Grace Briggs (wife of Walter Crawshaw Briggs). Effects $£ 258 \mathrm{~s}$.

FALL : George of 74 Reforne Easton Portland Dorsetshire died 11 March 1941 at Military Hospital Bath Probate Blandford $\gamma^{21}$ May to Alice Maud Fall widow. Effects 2577 9s. 5d. Gronthe brost 9 "augast 1948.

FALL Mary Josephine otherwise Marion of 32 St. Georges-road Ramsgate (wife of Robert Alexander Fall) died 17 July 1941 at 2 Sandhurst Afghan-road Reading-street Broadstairs Kent Administration Llandudno 23 August to the said Robert Alexander Fall retired commercial traveller. Effects $£ 48$ 16s. 2 d.

Notes: This is an image of part of the probate records for 1941 . Each record notes the name of the deceased individual, their address at time of death, as well as their wealth. 
Figure 3: TIME SERIES OF WEALTH INEQUALITY BY BOMBING INTENSITY

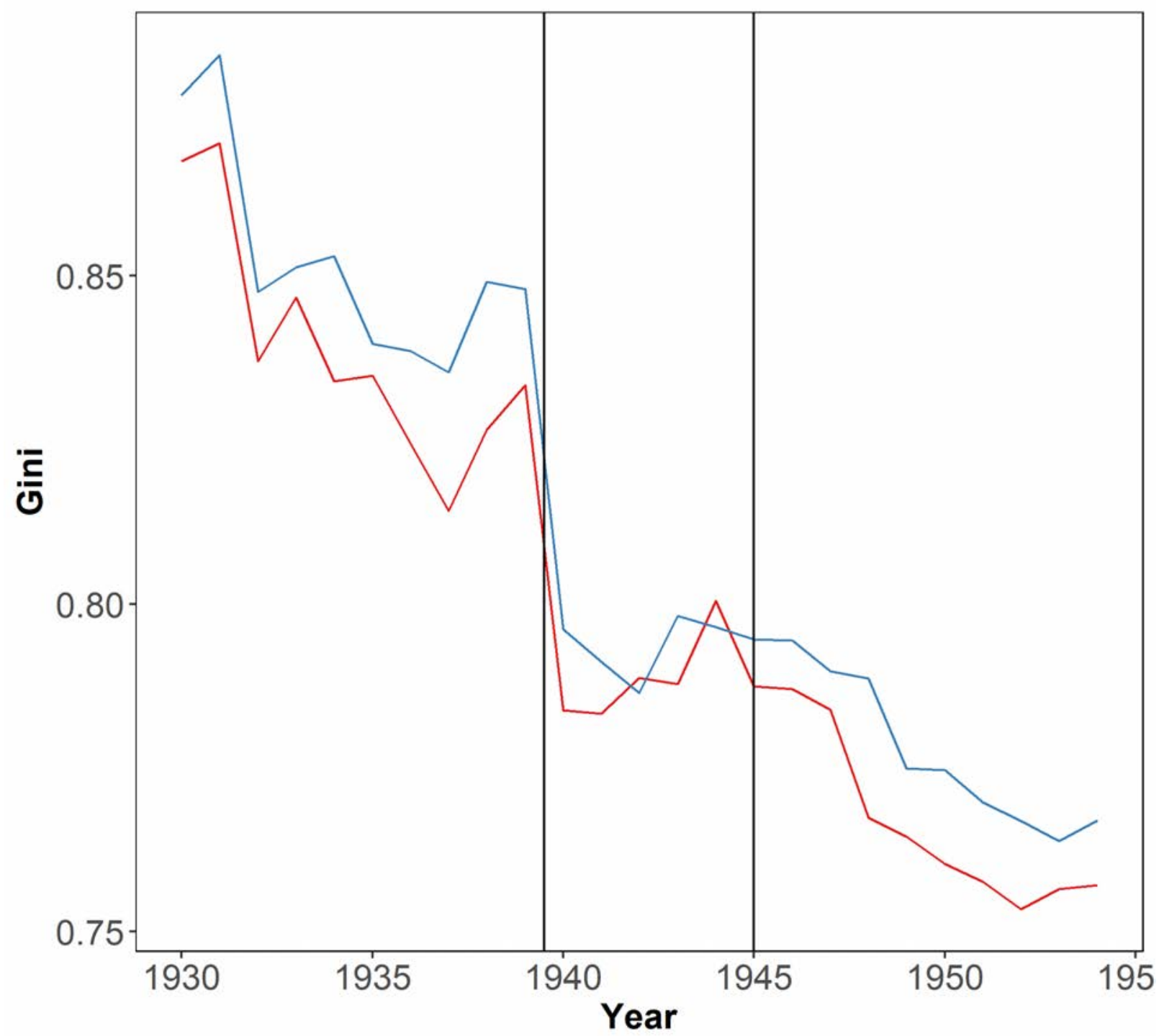

Bombing Intensity (Binary) $-0-1$

Notes: This figure plots the average wealth Gini coefficient across registration districts by year. We compute two time series, split by Bombing Intensity. Vertical lines indicate the the start and end of WWII. 
Figure 4: Wealth inequality COEFFicient Plot

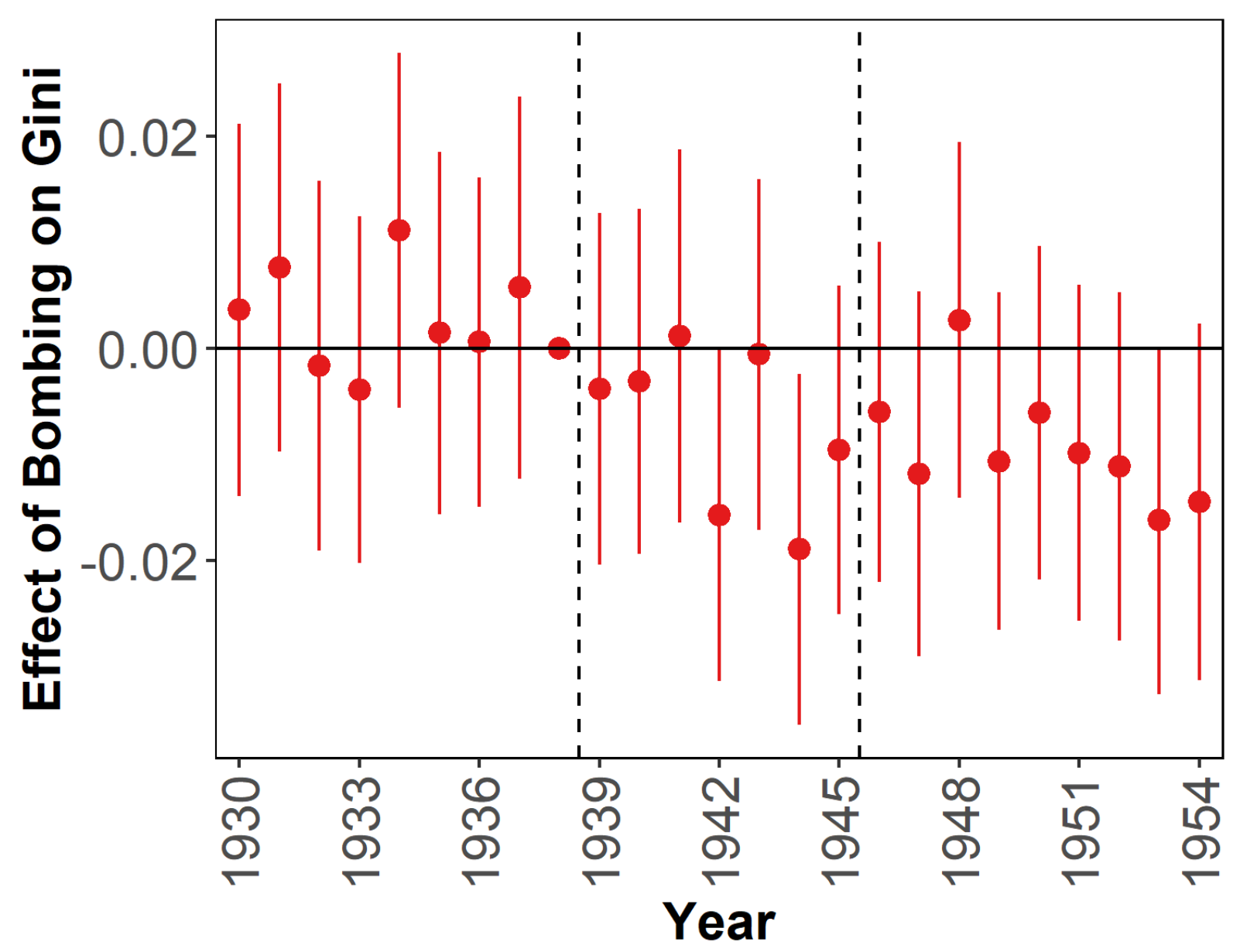

Notes: All regressions are estimated using OLS. The unit of observation is a registration district by year. Gini index is the wealth Gini coefficient for individuals in a registration district who passed away in a particular year and who were probated. Bombing Intensity (Binary) is the median split of bombing intensity, which is defined as the $\frac{\text { number of raids }}{\text { square } \mathrm{km}}$ between 1940 and 1945, with 1 being above median and 0 being below median. Each regression includes a full set of time and unit fixed effects. We express all estimated effects relative to 1938. Standard errors are clustered at the unit level. Vertical lines indicate the the start and end of WWII. The p-value for a joint F-test that the treatment effect coefficients for years $1930-1938$ are jointly 0 is 0.12 . The p-value for a joint F-test that the treatment effect coefficients for years $1939-1954$ are jointly 0 is 0.006401 . 
Figure 5: WEALTh INEQUALITY HETEROGENEOUS EFFECTS

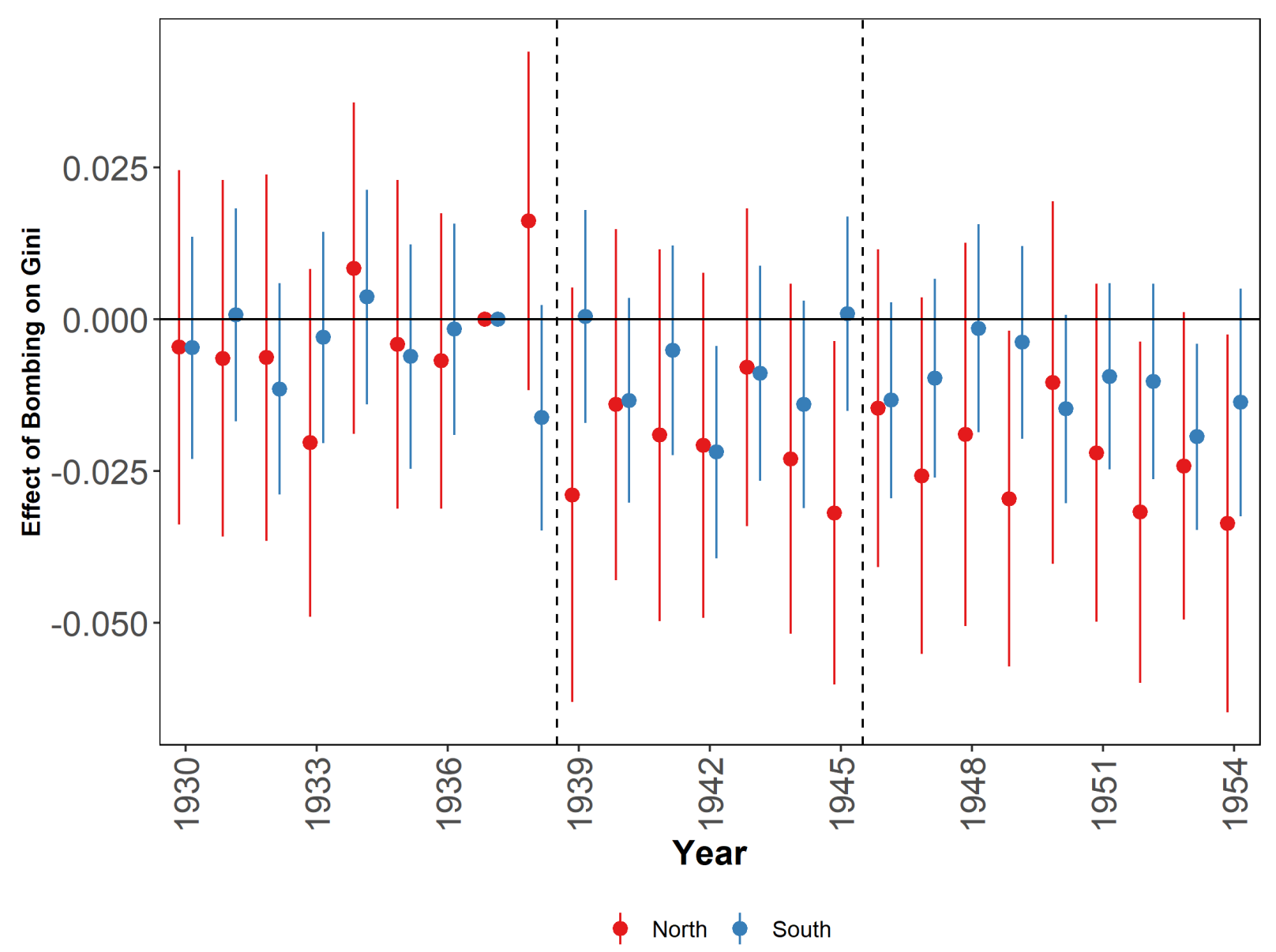

Notes: All regressions are estimated using OLS. The unit of observation is a registration district by year. Gini index is the wealth Gini coefficient for individuals in a registration district who passed away in a particular year and who were probated. Bombing Intensity (Binary) is the median split of bombing intensity, which is defined as the $\frac{\text { number of raids }}{\text { square } \mathrm{km}}$ between 1940 and 1945, with 1 being above median and 0 being below median. Each regression includes a full set of time and unit fixed effects. North is defined as units of observation that are above the median latitude of all units. South is defined analogously. Omitted year is 1937 instead of the standard 1938 because 1938 in the North is an outlier. Standard errors are clustered at the unit level. Vertical lines indicate the the start and end of WWII. 
Figure 6: Time SERIES OF votes FOR LABOUR By BOMBING INTENSITY

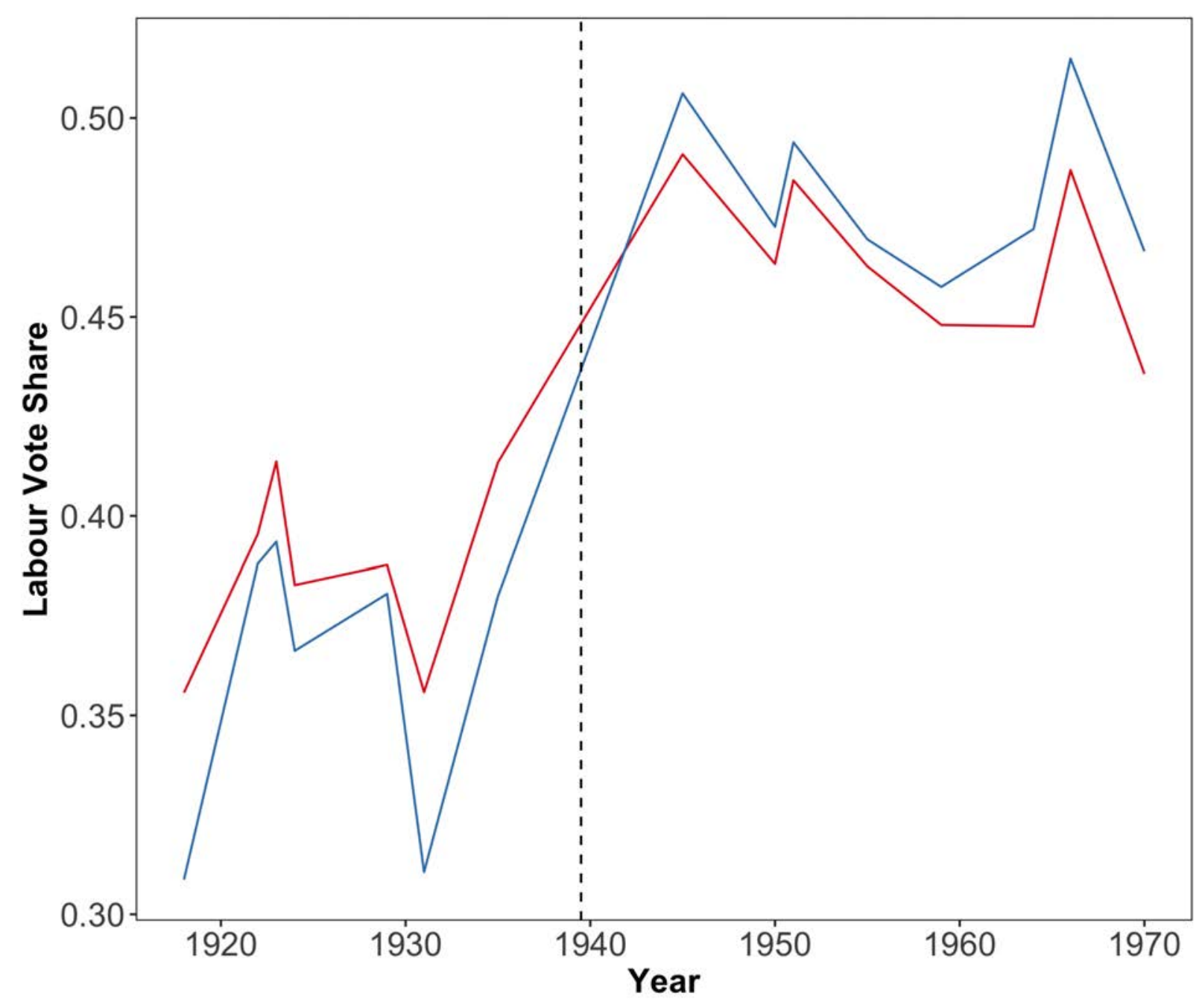

Bombing Intensity (Binary) $-0-1$

Notes: This figure plots the average vote share for the Labour party across constituencies by year. We compute two time series, split by Bombing Intensity. A vertical line indicates the start of WWII. 
Figure 7: Votes For LABOUR COEFFICIENT PLOT

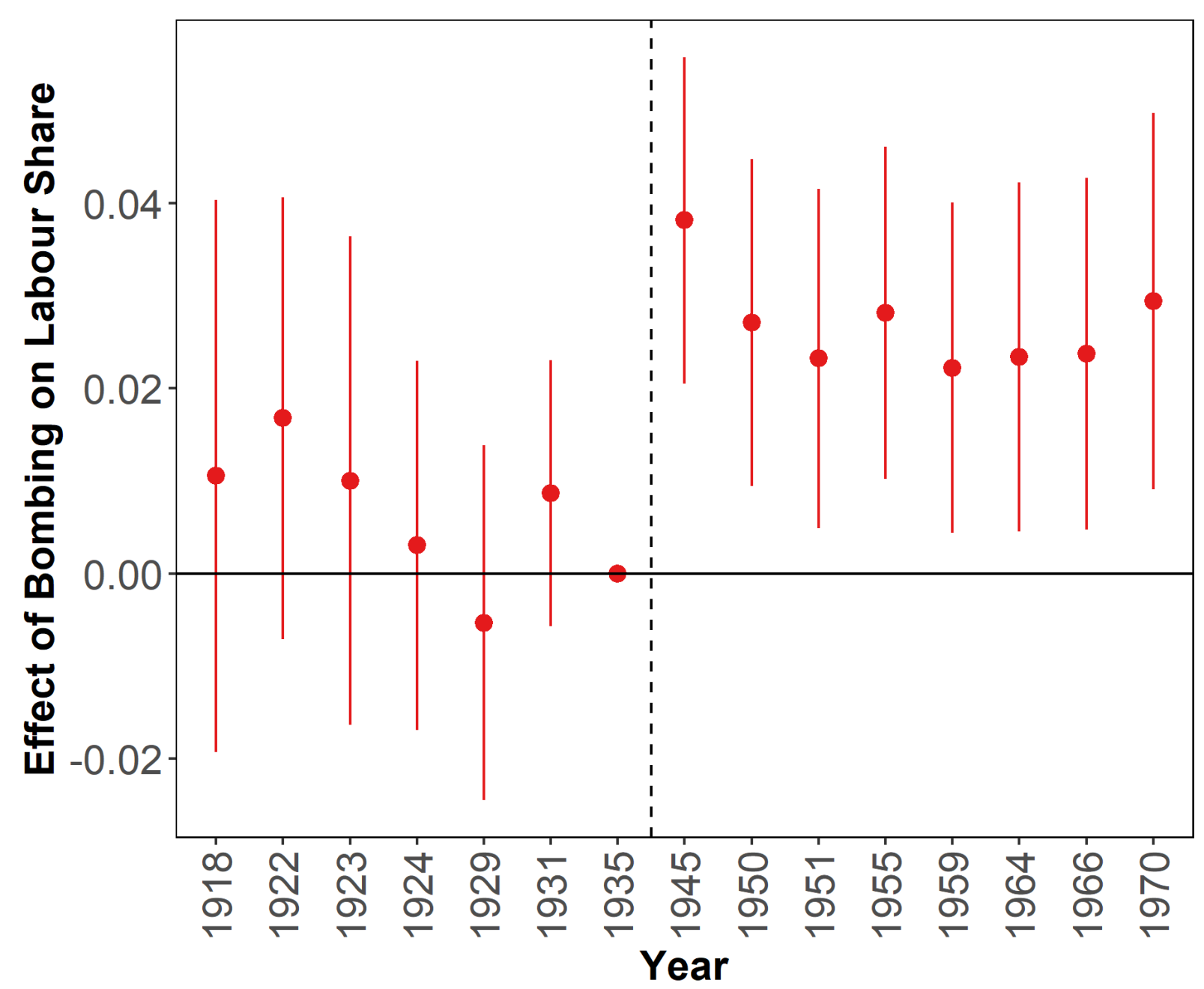

Notes: The unit of observation is a constituency by year. Labour Vote Share is the share of votes for the Labour party in a constituency. Bombing Intensity (Binary) is the median split of bombing intensity, which is defined as the $\frac{\text { number of raids }}{\text { square } \mathrm{km}}$ between 1940 and 1945, with 1 being above median and 0 being below median. Each regression includes a full set of time and unit fixed effects. We express all estimated effects relative to 1935. Standard errors are clustered at the unit level. A vertical line indicates the start of WWII. The p-value for a joint F-test that the treatment effect coefficients for years 1918 - 1935 are zero is 0.45 . The P-value for a joint F-test that the treatment effect coefficients for years $1945-1970$ are zero is $2.792 e^{-7}$. 
Figure 8: Votes for LABour Heterogeneous EFFECtS

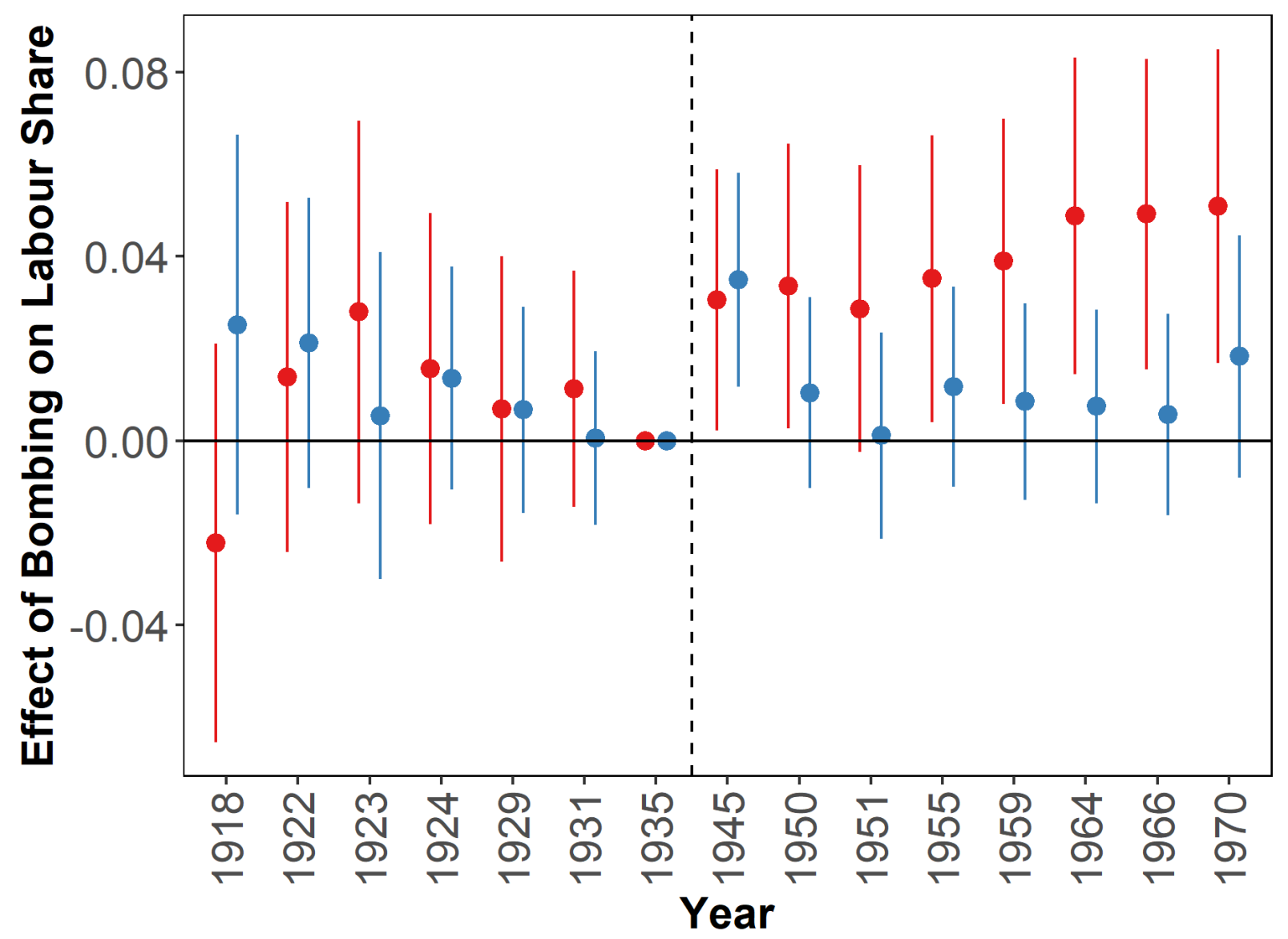

Region $\phi$ North $\phi$ South

Notes: The unit of observation is a constituency by year. Labour Vote Share is the share of votes for the Labour party in a constituency. Bombing Intensity (Binary) is the median split of bombing intensity, which is defined as the $\frac{\text { number of raids }}{\text { square km }}$ between 1940 and 1945, with 1 being above median and 0 being below median. Each regression includes a full set of time and unit fixed effects. North is defined as units of observation that are above the median latitude of all units. South is defined analogously. We express all estimated effects relative to 1935. Standard errors are clustered at the unit level. A vertical line indicates the start of WWII. 
Figure 9: Per capita wealth coefficient Plot

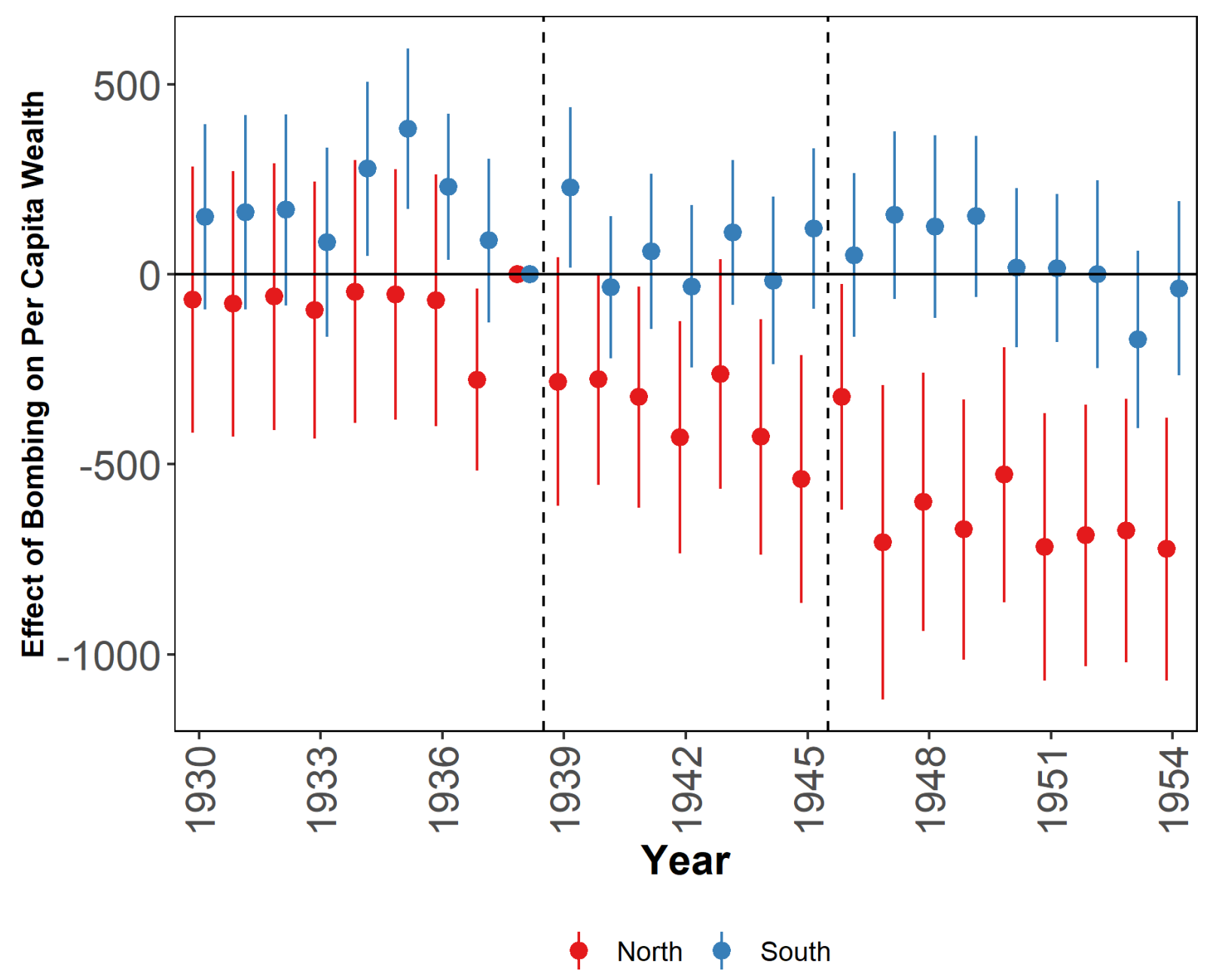

Notes: All regressions are estimated using OLS. The unit of observation is a registration district by year. Per Capita Wealth is the average per capita wealth in a registration district for probated individuals. Bombing Intensity (Binary) is the median split of bombing intensity, which is defined as the $\frac{\text { number of raids }}{\text { square } \mathrm{km}}$ between 1940 and 1945, with 1 being above median and 0 being below median. Each regression includes a full set of time and unit fixed effects. North is defined as units of observation that are above the median latitude of all units. South is defined analogously. We express all estimated effects relative to 1938. Standard errors are clustered at the unit level. 
Figure 10: MAP OF BF 109E RADIUS AND BOMBING INTENSITY

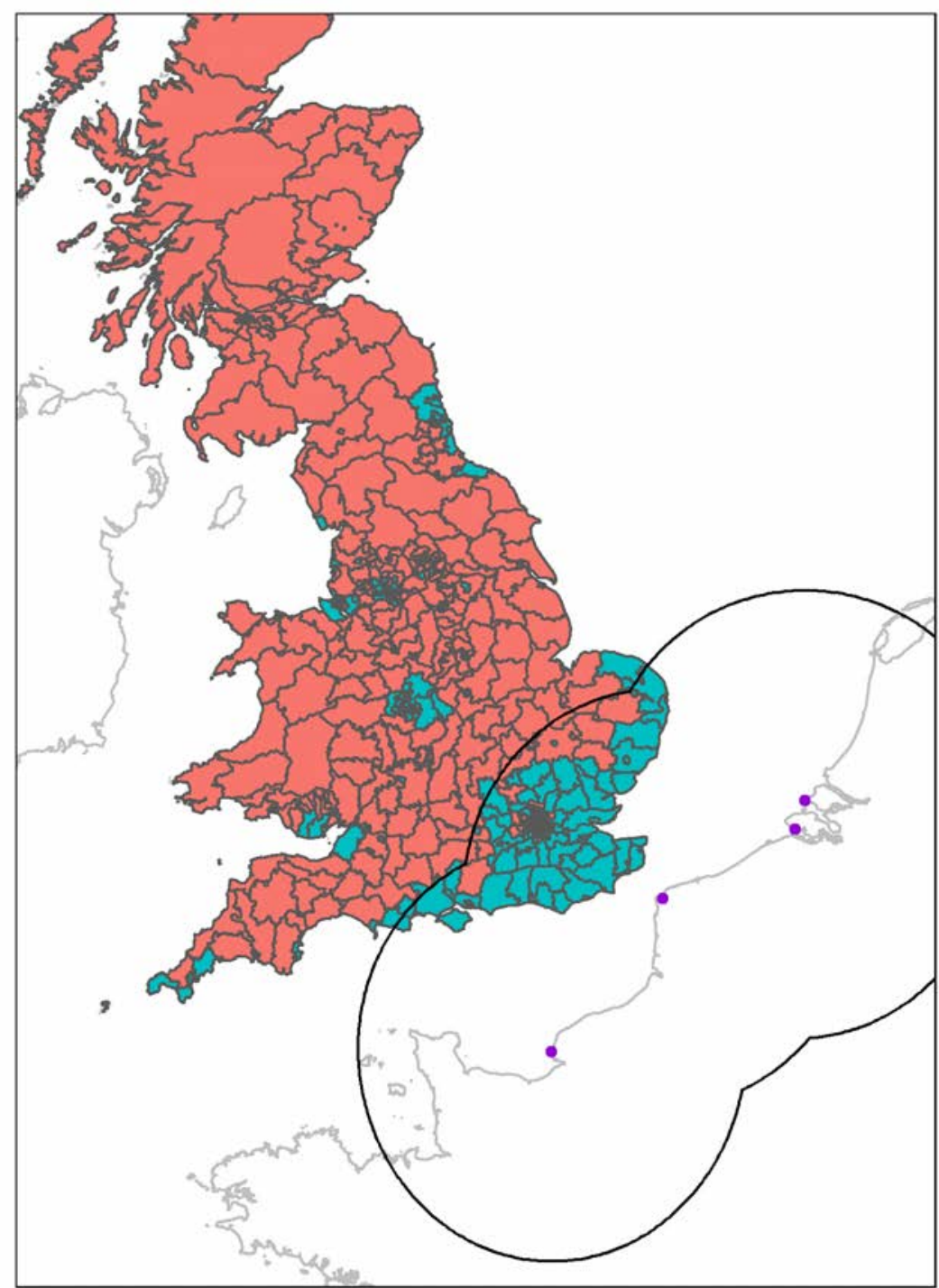

\section{Bombing Intensity (Binary) $\square 0 \square 1$}

Notes: This map plots the range of the BF 109E from its Battle of Britain bases and bombing intensity. Bombing Intensity (Binary) is the median split of bombing intensity, which is defined as the number of raids between 1940 and 1945, with 1 being above median and 0 being below median. Purple dots are main BF $109 \mathrm{E}$ bases used during Battle of Britain. The black outline is the range of the BF 109E from any base and is constructed by taking the union of 125 mile radii around each base. 
Figure 11: WeAlth INEQUALITy RD COEFFicient PLOT
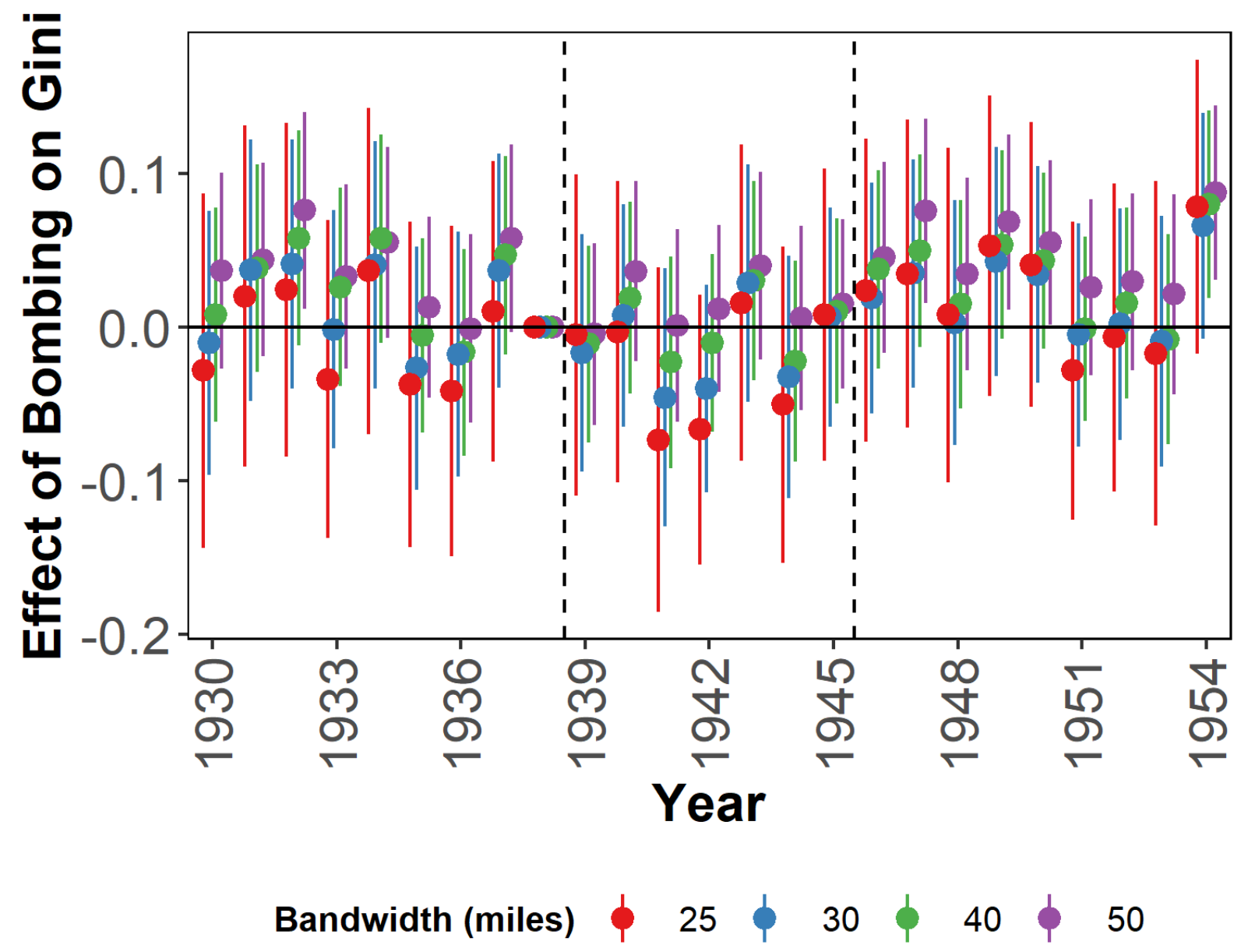

Notes: The unit of observation is a registration district by year. Gini index is the wealth Gini coefficient for individuals in a registration district who passed away in a particular year and who were probated. Bandwidth is defined using shortest distance from a BF 109E base to any part of unit. We use a uniform kernel. We express all estimated effects relative to 1938. We define a unit of observation to be in range of the BF 109E if any part of it is within range. Each regression includes a full set of time and unit fixed effects. Standard errors are clustered at the unit level. Vertical lines indicate the the start and end of WWII. Because we have 15 endogenous variables, we compute 15 first stage F-statistics. The smallest F-statistics across all endogenous variables and across all bandwidths is 17.6. 
Figure 12: Votes For LABOUR RD COEFFiCIENT PLOT
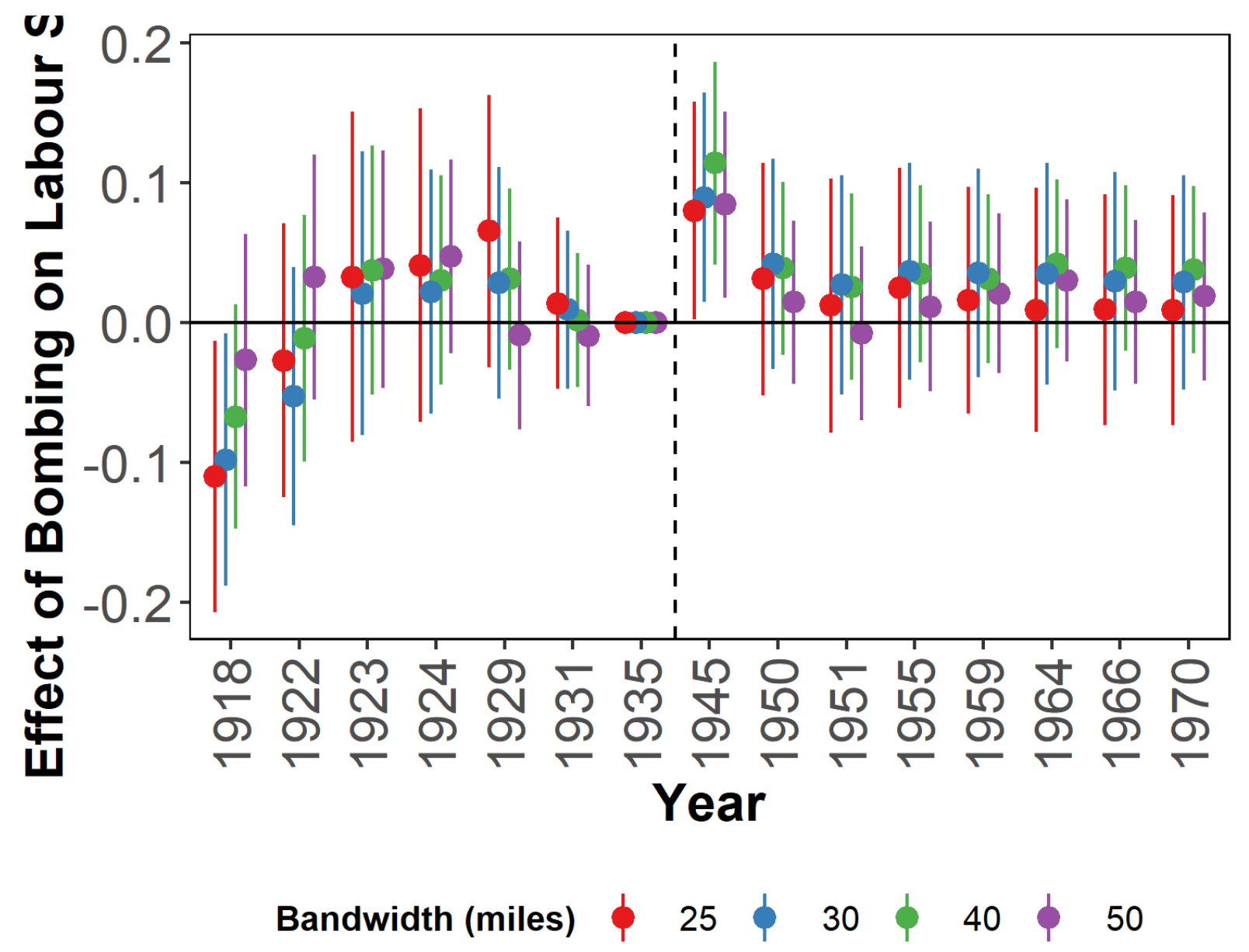

Notes: The unit of observation is a constituency by year. Labour Vote Share is the share of votes for the Labour party in a constituency. Bandwidth is defined using shortest distance from a BF 109E base to any part of unit. We use a uniform kernel. We express all estimated effects relative to 1935. We define a unit of observation to be in range of the BF 109E if any part of it is within range. Each regression includes a full set of time and unit fixed effects. Standard errors are clustered at the unit level. A vertical line indicates the start of WWII. Because we have 15 endogenous variables, we compute 15 first stage F-statistics. The smallest F-statistics across all endogenous variables and across all bandwidths is 14.1. 
Table 1: Descriptive Statistics

\begin{tabular}{|c|c|c|c|c|}
\hline Outcome variable: & $\begin{array}{c}\text { NuMBER } \\
\text { OF OBSER- } \\
\text { VATIONS IN } \\
\text { MEDIAN } \\
\text { PERIOD }\end{array}$ & $\begin{array}{l}\text { Mean of } \\
\text { Outcome }\end{array}$ & $\begin{array}{c}\text { SD OF } \\
\text { OutCOME }\end{array}$ & $\begin{array}{c}\text { NuMBER OF } \\
\text { PERIODS }\end{array}$ \\
\hline Labour Vote Share & 576 & 0.44 & 0.16 & 10 \\
\hline Wealth Gini coefficient & 585 & 0.81 & 0.10 & 25 \\
\hline
\end{tabular}

Table 2: Analysis of counterfactual Parliamentary elections

\begin{tabular}{|c|c|c|c|c|}
\hline $\begin{array}{c}\text { ELECTION } \\
\text { YEAR }\end{array}$ & $\begin{array}{l}\text { SEATS WON } \\
\text { BY LABOUR } \\
\text { IN SAMPLE }\end{array}$ & $\begin{array}{c}\text { SEATS WON } \\
\text { BY CONSER- } \\
\text { VATIVES IN } \\
\text { SAMPLE }\end{array}$ & $\begin{array}{c}\text { SEATS } \\
\text { FLIPPED BY } \\
\text { BOMBING }\end{array}$ & $\begin{array}{c}\text { ELECTION } \\
\text { FLIPPED BY } \\
\text { BOMBING }\end{array}$ \\
\hline 1931 & 26 & 311 & 0 & 0 \\
\hline 1935 & 94 & 278 & 0 & 0 \\
\hline 1945 & 292 & 167 & 32 & 0 \\
\hline 1950 & 188 & 169 & 29 & 1 \\
\hline 1951 & 163 & 181 & 23 & 0 \\
\hline
\end{tabular}

Notes: This table analyzes five elections between 1931 and 1951. For each, we show the number of seats Labour won in column (1). In column (2) we show the number of seats the Conservatives won. These seats do not always add up to the same total, as we do not analyze votes for the Liberal party and we miss data for a few constituencies. In column (3) we take our estimated effects of bombing on the Labour vote share for each individual election and compute how many seats would have flipped absent bombing. For example, in 1945 without bombing, Labour would have 227 and the Conservatives would have 172 . In column (4) we provide an indicator which elections would have flipped absent bombing. 
Table 3

Data Sources

Variable

\begin{tabular}{|c|c|c|}
\hline Variable & Source & Comment \\
\hline \multicolumn{3}{|c|}{ Dependent Variables } \\
\hline Labour Vote Share & $\begin{array}{l}\text { Parliamentary Commons } \\
\text { Library }\end{array}$ & 1918-2019 data \\
\hline Gini and Per Capita Wealth & UK Probate Calendar & $\begin{array}{l}\text { Probates contain individual level data, which can } \\
\text { be aggregated for other economic outcomes. }\end{array}$ \\
\hline \multicolumn{3}{|c|}{ Treatment Variables } \\
\hline Bombing Intensity & $\begin{array}{l}\text { www.warstateandsociety.com } \\
\text { /Bombing-Britain }\end{array}$ & $\begin{array}{l}\text { Contains number of raids. We normalize by area } \\
\text { of unit, which are described below. }\end{array}$ \\
\hline \multicolumn{3}{|c|}{ Unit Variables } \\
\hline Constituencies & Vision of Britain & $\begin{array}{l}\text { contains shapefiles for England, Wales, and } \\
\text { Scotland. We aggregate across all years as well, } \\
\text { from 1918-1970. }\end{array}$ \\
\hline Registration Districts & Vision of Britain & $\begin{array}{l}\text { contains shapefiles for England and Wales. We } \\
\text { take the districts in } 1911 \text { as static. }\end{array}$ \\
\hline \multicolumn{3}{|c|}{ Airfield data } \\
\hline Airfields & $\begin{array}{l}\text { All airfields found } \\
\text { http://www.ww2.dk/ }\end{array}$ & $\begin{array}{l}\text { We subset to those used during Battle of Britian, } \\
\text { when BF 109E's range limitation played a role, } \\
\text { as described in World War II: A New History }\end{array}$ \\
\hline Distance to Airfields & ARCGIS & Calculated using unit and airfield locations. \\
\hline
\end{tabular}




\section{References}

Acemoglu, D. and J. A. Robinson (2000). Why did the west extend the franchise? growth, inequality and democracy in historical perspective. Quarterly Journal of Economics 115: 4, 1167-1199.

Addison, P. (1975). The Road to 1945. London: Pimlico.

Aidt, T. S. and P. S. Jensen (2009). The taxman tools up: An event history study of the introduction of the personal income tax. Journal of Public Economics 91: 1-2, 160-175.

Aidt, T. S. and P. S. Jensen (2014). Workers of the world, unite! franchise extensions and the threat of revolution in europe, 1820-1938. European Economic Review 91: 1-2, 52-75.

Alvaredo, F., A. B. Atkinson, and S. Morelli (2018). Top wealth shares in the uk over more than a century. Journal of Public Economics 162, 26-47.

Baldwin, P. (1990). The Politics of Social Solidarity: Class Bases of the European Welfare State 1875-1975. CamCambridge University Press.

Besley, T. and T. Persson (2011). Pillars of Prosperity. Princeton: Princeton University Press.

Calder, A. (1991). The Myth of the Blitz. Jonathan Cape.

Crowcroft, R. and K. Theakston (2013). The fall of the attlee government, 1951. In T. H. et al. (eds.) (Ed.), How Labour Governments Fall. Palgrave Macmillan.

Cummins, N. (2021). Where is the middle class? evidence from 60 million english death and probate records, 1892-1992. The Journal of Economic History, 1-46.

Davis, D. R. and D. E. Weinstein (2002). Bones, bombs, and break points: The geography of economic activity. American Economic Review 92: 5, 1269-1289.

Dell, M. and P. Querubín (2018). Nation building through foreign intervention. Quarterly Journal of Economics 133: 2, 701-764.

Dryzek, J. H. and R. E. Goodin (1986). Risk-sharing and social justice: The motivational foundations of the post-war welfare state. British Journal of Political Science 16:1, 1-34.

Edgerton, D. (2018). War and the development of the british welfare state. In K. P. Herbert Obinger and P. Starke (Eds.), Warfare and Welfare: Military Conflict and Welfare State Development in Western Countries. Oxford: Oxford University Press. 
Goodin, R. and J. H. Dryzek (1995). Justice deferred: Wartime rationing and postwar welfare policy. Politics and Society 23:1, 49-73.

Harris, J. (1992). War and social history: Britain and the home front during the second world war. Contemporary European History 1:1, 17-35.

Harrison, A. and A. Atkinson (1978). Distribution of Personal Wealth in Britan. CUP Archive.

Hennessey, P. (2006). Never Again: Britain 1945-1951. London: Penguin.

Jefferys, K. (1987). British politics and social policy during the second world war. The Historical Journal 30:1, 123-144.

Kuznets, S. (1955). Economic growth and income inequality. American Economic Review 45:1, 1-28.

Kynaston, D. (2007). Austerity Britain: 1945-1951. London: Bloomsbury.

Lowe, R. (1990). The second world war, consensus, and the foundation of the welfare state. Twentieth Century British History 1:2, 152-182.

Mawdsley, E. (2020). World War II: A new history. Cambridge: Cambridge University Press.

McCallum, R. and A. Readman (1964). The British General Election of 1945. London: Frank Cass.

McNab, C. (2012). Hitler's Eagles: The Luftwaffe 1933-45. London: Bloomsbury Publishing.

Miguel, E. and G. Roland (2011). The long-run impact of bombing vietnam. Journal of Development Economics 96: 1, 1-15.

Murray, W. (2015). Strategy For Defeat: The Luftwaffe, 1933-1945 [Illustrated Edition]. Pickle Partners Publishing.

Piketty, T. (2003). Income inequality in france, 1901-1998. Journal of political economy 111(5), 1004-1042.

Piketty, T. (2011). On the long-run evolution of inheritance: France, 1820-2050. Quarterly Journal of Economics 126, 1071-1131.

Piketty, T. and E. Saez (2014). Inequality in the long run. Science 344, 838-843.

Ponting, C. (1993). 1940: Myth and Reality. Chicago: Ivan R. Dee.

Scheidel, W. (2017). The Great Leveller. Princeton University Press. 
Scheve, K. and D. Stasavage (2016). Taxing the Rich: A History of Fiscal Fairness in the United States and Europe. Cambridge: Cambridge University Press.

Smith, H. L. (1986). War and Social Change: British Society in the Second World War. Manchester: Manchester University Press.

Therborn, G. (1977). The rule of capital and the rise of democracy. New Left Review I (103), 3-41.

Tilly, C. (1990). Coercion, Capital and European States. Hoboken: Blackwell Publishers.

Titmuss, R. M. (1950). Problems of Social Policy. London: Policy Press.

Titmuss, R. M. (2001). War and social policy. In H. G. Alcock, Pete and A. O. eds. (Eds.), Welfare and wellbeing: Richard Titmuss's contribution to social policy. London: Policy Press.

Todman, D. (2020). Britain's War: A New World 1942-194\%. Oxford: Oxford University Press.

Watson, C., E. Uberoi, and P. Loft (2020). General election results from 1918 to 2019. House of Commons Library.

Williamson, J. (1985). Did British Capitalism Breed Inequality? Boston: Allen \& Unwin. 